\title{
Structure rearrangement during rennet coagulation of milk modifies curd density
}

\author{
J. C. Amaro-Hernández, ${ }^{1}$ G. I. Olivas, ${ }^{1}$ C. H. Acosta-Muñiz, ${ }^{1}$ N. Gutiérrez-Méndez, ${ }^{2}$ ๑) and D. R. Sepulveda* ${ }^{1 *}$ \\ ${ }^{1}$ Centro de Investigacion en Alimentacion y Desarrollo A.C., Unidad Cuauhtemoc, Av. Rio Conchos S/N, Parque Industrial, Ciudad Cuauhtemoc, \\ Chihuahua, Mexico, C.P. 31570 \\ ${ }^{2}$ Universidad Autonoma de Chihuahua, Facultad de Ciencias Quimicas, Chihuahua, Chihuahua, Mexico, C.P. 31570
}

\section{ABSTRACT}

Milk curds are a semisolid structure resulting from the enzymatic coagulation of milk, consisting mainly of paracasein micelles, fat globules, and whey. This gel undergoes a series of changes in its composition and structure during setting and curing, affecting curd density. The present study investigated the composition and density of inoculated and noninoculated milk curds during a 60 -min curing period conducted at 30,35 , and $40^{\circ} \mathrm{C}$. The purpose of the study was to determine the density changes occurring in the protein phase of curds during curing under different conditions of temperature and $\mathrm{pH}$ to understand the nature of the structural changes happening in the paracasein matrix. Noninoculated curd density values oscillated between 1.0247 and $1.0294 \mathrm{~g} / \mathrm{cm}^{3}$ after $60 \mathrm{~min}$ of curing, whereas inoculated treatments showed values between 1.0222 and $1.0321 \mathrm{~g} /$ $\mathrm{cm}^{3}$. This small difference in density between the studied samples was surprising because the whey content of samples differed greatly. Density of the protein phase reached values of 1.8002 and $1.4388 \mathrm{~g} / \mathrm{cm}^{3}$ for noninoculated and inoculated curds, respectively, after $60 \mathrm{~min}$ of curing. Two independent mechanisms involved in the development of the protein-based structure of curds were identified upon comparison of the development of protein phase density in inoculated and noninoculated curds. Although the larger increase in protein phase density observed in noninoculated curds was probably due to the concurrent action of calcium-mediated electrostatic bonds and temperature-dependent hydrophobic bonds, inoculated curds showed a lower protein phase density caused by calcium solubilization and by a decrease in the net charge of paracasein micelles induced by $\mathrm{pH}$ reduction.

Key words: curd density, curd temperature, curd $\mathrm{pH}$, curd protein phase density, curd syneresis

Received May 21, 2019.

Accepted December 6, 2019.

*Corresponding author: dsepulveda@ciad.mx

\section{INTRODUCTION}

Rennet coagulation of milk is a physicochemical phenomenon that has been known for millennia (Sørensen et al., 2011). During rennet coagulation, liquid milk turns into a semisolid gel that evolves through time (curing), losing whey and gaining firmness (O'Callaghan, 2011). Although there is a consensus identifying paracasein micelles as the milk components responsible for the formation of the semisolid matrix, the actual mechanism through which the structure of the gel is formed and evolves through time is not well known (Fox et al., 2017).

Shrinking of curds after gelling suggests the rearrangement of paracasein micelles forming the gel network (Lucey, 2011). Such rearrangement is likely caused by an increment in the number of protein-protein interactions, leading to the formation of thicker paracasein micelle strands and thus reducing the available space for whey (Meakin, 1987). Intramicellar rearrangements, individual micelle shifts, and strand rearrangements have been suggested as potential mechanisms involved in rennet-induced casein gel curing (Mellema et al., 2000). Particle fusion (disintegration of the micellar structure within the newly created hyperdimensional strands) has also been suggested as a relevant phenomenon potentially taking place during milk gel aging (Mellema et al., 2002).

These structural rearrangements, together with composition changes caused by syneresis, undoubtedly modify the density of curds. Three main phases may be identified within the gel structure: fat globules, which for structural purposes can be considered an inert filler with homogeneous physical properties (Horne and Banks, 2004); liquid whey, also a structure-filling substance with homogeneous physical properties (Walstra et al., 2005; Yadav et al., 2015); and a proteinbased solid-like network comprising mainly paracasein micelles, minerals in soluble and insoluble form, and some hydration whey (Akkerman, 1992; Ong et al., 2011; Hickey et al., 2015). This third phase, the most complex of the 3 , has unknown and changing composi- 
tion and physical properties, which depend on environmental conditions ( $\mathrm{pH}$, ionic force, temperature) and the degree of advance of the curing process. Paracasein micelles (spherical, highly hydrated, open structures in liquid milk) may also change their configuration during the curing process, contributing to the modification of the physical properties of the proteinaceous part of the structure (Dalgleish and Law, 1988).

Taking into account all of these conditions, in the present study the composition and density of rennetcoagulated milk were monitored during curing processes with and without microbial acidity development in an attempt to estimate changes in the density of the protein-based network through measurement of the density of curds, whey, and fat phases as well as their relative abundances. It is expected that this knowledge will shed some light on the nature of the structural rearrangements happening in the paracasein network during aging of milk gels.

\section{MATERIALS AND METHODS}

The density and composition of curds were measured during gel curing under different conditions of acidity and temperature. The density of the protein phase was calculated based on the density and relative abundance of the rest of the curd components.

\section{Curd Manufacture and Conditioning}

Pasteurized bovine whole milk (2 L/treatment) was conditioned at 3 temperatures $\left(30,35\right.$, and $\left.40^{\circ} \mathrm{C}\right)$ with and without the addition of lactic cultures. For inoculated samples, $0.8 \mathrm{U}$ of lactic acid bacteria was added (RTS 743, Chr. Hansen, Hørsholm, Denmark). Milk was then coagulated by adding $100 \mu \mathrm{L}$ (50 international milk-clotting units) of a solution of Chy-Max M 1000 (Ch. Hansen). Subsequently, each mixture was stirred and left undisturbed for $30 \mathrm{~min}$ to complete curd formation.

After obtaining a uniform gel, it was cut into cubes of about $1 \mathrm{~cm}$, leaving the curd pieces in the vat to start the undisturbed curing period. Curd samples were taken during this stage $(0,15,30,45$, and $60 \mathrm{~min})$, considering time 0 as the moment immediately following cut. Composition, pH, and density were evaluated for each sample at each sampling time.

\section{Composition and Physicochemical Analyses}

Moisture and fat contents of curds were measured using the AOAC International (2002) method 926.08 and AOAC International (2006) method 989.05 test protocols, respectively. Soluble solids content of whey was measured using the AOAC International (2002) method 990.20 test protocol to determine the whey content of curds based on their measured moisture content. The $\mathrm{pH}$ was measured potentiometrically (Hanna HI5222, Hanna Instruments, Woonsocket, RI).

Whey and fat densities were measured using a 2-mL pycnometer (Hubbard/Carmick, Pyrex, Greencastle, PA). Pure milk fat was obtained using the Gerber method. Curd density was determined via the water displacement method using a $25-\mathrm{mL}$ pycnometer (Hubbard/Carmick, Pyrex) as follows. Curd samples ( $\sim 3 \mathrm{~g})$ were placed inside the $25-\mathrm{mL}$ pycnometer and weighed on an analytical balance after taring. Afterward, the pycnometer was filled to the $25-\mathrm{mL}$ mark with distilled water. The weight increase caused by water addition was then used to estimate the water volume, considering water density. Curd sample volume was determined by subtracting the estimated water volume from the pycnometer's $25-\mathrm{mL}$ nominal volume. Curd density was obtained by dividing curd weight by curd volume.

\section{Determination of Protein Phase Density}

Walstra et al. (2005) established that the density $(\rho)$ of a multicomponent mixture such as curds can be determined by adding the quotients obtained from dividing the mass fraction of each one of its individual components $\left(m_{x}\right)$ by their respective densities $\left(\rho_{x}\right)$ :

$$
\frac{1}{\rho}=\sum\left(\frac{m_{x}}{\rho_{x}}\right)
$$

Curds comprise whey, fat, and a protein phase of complex composition (mainly casein, whey, and minerals). The mass fraction of each of these 3 components may be calculated by dividing their respective measured weights over the total curd weight. For this purpose, the weight of the protein phase may be calculated by subtracting the measured weights of fat and whey from the total curd weight. Considering that fat, whey, and curd densities were experimentally determined, Equation 1 may be solved for protein phase density ( $\left.\rho_{\text {protein phase }}\right)$, yielding Equation 2:

$$
\rho_{\text {protein phase }}=\frac{m_{\text {protein phase }}}{\left(\frac{1}{\rho_{\text {curds }}}\right)-\left(\frac{m_{\text {whey }}}{\rho_{\text {whey }}}\right)-\left(\frac{m_{\text {fat }}}{\rho_{\text {fat }}}\right)},
$$

where $m_{f a t}, m_{\text {whey }}$, and $m_{\text {protein phase }}$ stand for the mass fraction of fat, whey, and the protein phase, respectively, $\rho_{\text {fat }}, \rho_{\text {whey }}$, and $\rho_{\text {curds }}$ stand for the density of fat, whey, and curds, respectively. 


\section{Statistical Analysis}

The experiment was conducted in triplicate. Analyses of variance were conducted for each response variable, considering a $2 \times 3 \times 5$ factorial experimental design (2 inoculation levels: inoculated and noninoculated; 3 temperature levels: 30,35 , and $40^{\circ} \mathrm{C} ; 5$ time levels: 0 , 15, 30, 45, and $60 \mathrm{~min})$, using SAS statistical software (SAS Institute Inc., Cary, NC), considering a significance level of $P \leq 0.01$.

\section{RESULTS AND DISCUSSION}

\section{$\mathrm{pH}$}

The $\mathrm{pH}$ of studied curd samples is shown in Figure 1. As expected, higher incubation temperatures caused a larger decrease in $\mathrm{pH}$ than lower temperatures, whereas noninoculated samples did not develop any acidity throughout the studied time. The $\mathrm{pH}$ of all studied samples was around 6.5 before conducting the tests. Lactic acid bacteria inoculation took place $90 \mathrm{~min}$ before the time presented as time 0 in Figure 1. Inoculated samples showed linear acidification trends with respect to time, displaying coefficients of determination of $0.9577,0.9776$, and 0.9965 at 30,35 , and $40^{\circ} \mathrm{C}$, respectively. Previously published studies reported similar acidification trends in inoculated curds. Gonçalves and Cardarelli (2019) used Streptococcus thermophilus and Lactobacillus delbrueckii for the manufacture of mozzarella cheese, inducing an acidity increase from a $\mathrm{pH}$ of 6.50 to 5.1 during a period of $60 \mathrm{~min}$.

Acidification plays an important role in curd setting and curing, influencing the physicochemical properties of casein micelles and therefore potentially modifying the density of the protein phase of curds. The enzymatic activity of chymosin is favored at lower $\mathrm{pH}$, increasing the rate of proteolysis, which is the first step in curd formation (Van den Bijgaart, 1988; Janhøj and Qvist, 2010). Acidity development also plays an important role in increasing the rate of aggregation of paracasein micelles during gel formation (Mellema et al., 2000), producing rearrangements inside the protein matrix that simultaneously result in a firmness increase and in greater whey expulsion (van Vliet et al., 2004). The $\mathrm{Z}$ potential of paracasein micelles increases gradually during acidity development (from -18 to $-11 \mathrm{mV}$ in a $\mathrm{pH}$ range of 6.7-5.5), causing a decrease in net negative charge and reducing the space between micelles (Van den Bijgaart, 1988; Janhøj and Qvist, 2010). Colloidal calcium phosphate from the interior of micelles is also dissociated at lower $\mathrm{pH}$, promoting the weakening of the micellar structure (Lodaite et al., 2000; Choi et al., 2015).

\section{Whey Content}

Figure 2 shows whey syneresis of curd samples during the $60 \mathrm{~min}$ of the study. Whey content of all studied samples was about $93 \mathrm{~g}$ of whey/100 g of curds at the beginning of the study. However, as gels cured, inoculated samples incubated at 35 and $40^{\circ} \mathrm{C}$ lost whey at a higher rate than the rest of the studied samples. No significant difference in whey content was found between noninoculated samples and the inoculated sample incubated at $30^{\circ} \mathrm{C}$, indicating that small decreases in $\mathrm{pH}$ (those resulting in $\mathrm{pH}$ values $>5.75$ ) do not cause a significant change in whey loss rate. All studied samples lost whey in a fairly linear trend $\left(\mathrm{R}^{2}\right.$ values between 0.9624 and 0.9932 ). Noninoculated samples, together with the inoculated sample incubated at $30^{\circ} \mathrm{C}$, lost whey at an average rate of $0.1408 \mathrm{~g}$ of whey/min. Inoculated samples incubated at 35 and $40^{\circ} \mathrm{C}$ lost whey at rates of 0.2113 and $0.4451 \mathrm{~g}$ of whey $/ \mathrm{min}$, respectively. It is important to point out that noninoculated samples lost some whey even though their $\mathrm{pH}$ remained constant during the study, suggesting that other factors besides $\mathrm{pH}$ play a relevant role in whey loss.

Several authors agree that treatments with acidified milk improve the properties of rennet curds during formation and maturation, including increasing firmness, whey displacement, and whey loss rate. Lodaite et al. (2000) evaluated the syneresis of blocks of curds of different thickness using $\mathrm{pH} 6.4$ and 6.0. These researchers measured the relative flow rate of whey and, using Darcy's law, concluded that curds with a greater degree

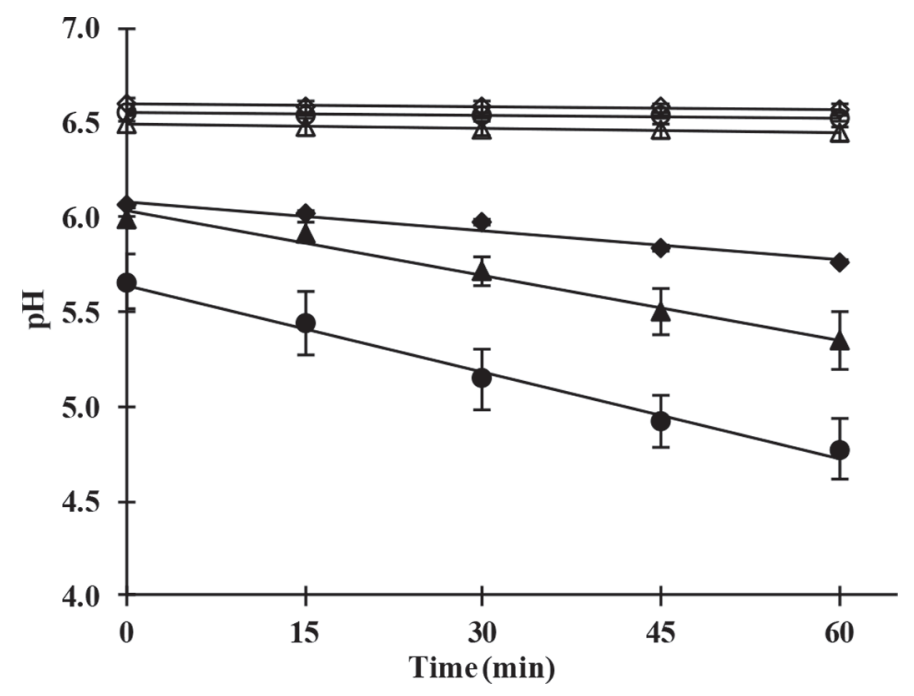

Figure 1. The $\mathrm{pH}$ development of inoculated and noninoculated curds incubated at 3 temperatures. Noninoculated samples are represented by empty symbols: $30^{\circ} \mathrm{C}(\diamond), 35^{\circ} \mathrm{C}(\Delta)$, and $40^{\circ} \mathrm{C}(\bigcirc)$. Inoculated samples are represented by filled symbols: $30^{\circ} \mathrm{C}(\bullet), 35^{\circ} \mathrm{C}$ $(\boldsymbol{\Delta})$, and $40^{\circ} \mathrm{C}(\bullet)$. Error bars indicate SD. 
of acidity and thickness show higher shrinkage due to whey loss. Van den Bijgaart (1988) studied the effect of the endogenous pressure inside curds on samples at $\mathrm{pH}$ $6.68,6.48$, and 6.33 and found that the internal pressure of curds was affected by $\mathrm{pH}$, reporting endogenous pressure values of $0.25,1.10$, and $2.00 \mathrm{~Pa}$, respectively. In a similar study, Marshall (1982) measured the syneresis of undisturbed curds during the maturation process at $\mathrm{pH} 6.6,6.3$, and 6.0 using a stainless steel mesh to prevent curd movement when collecting displaced whey, obtaining values of $0.2,0.35$, and $0.4 \%$ of whey loss, respectively.

The presence of some specific chemical bonds during aggregation is of great importance. Hydrophobic and electrostatic (calcium bridges) interactions give paracasein particles the ability to join together and form a 3-dimensional structure (Fox and Guinee, 2013). The increase in the number of links between molecules of paracasein produces a series of internal rearrangements in the protein network that manifests as shrinkage, as if the curd was naturally squeezed from the inside (Özilgen and Kauten, 1994; Lucey, 2014). Electrostatically driven internal changes are potentiated by lowering $\mathrm{pH}$ to about 5.2, causing an increase in the speed of molecular rearrangements, resulting in an increase in the permeability of the curd (van Vliet and Walstra, 1994; Janhøj and Qvist, 2010).

Hydrophobic interactions also play a transcendent role by giving a capillary force to the surface of undisturbed gels (hydrophobic regions oriented to the air). However, cutting and stirring (wetting) trigger the

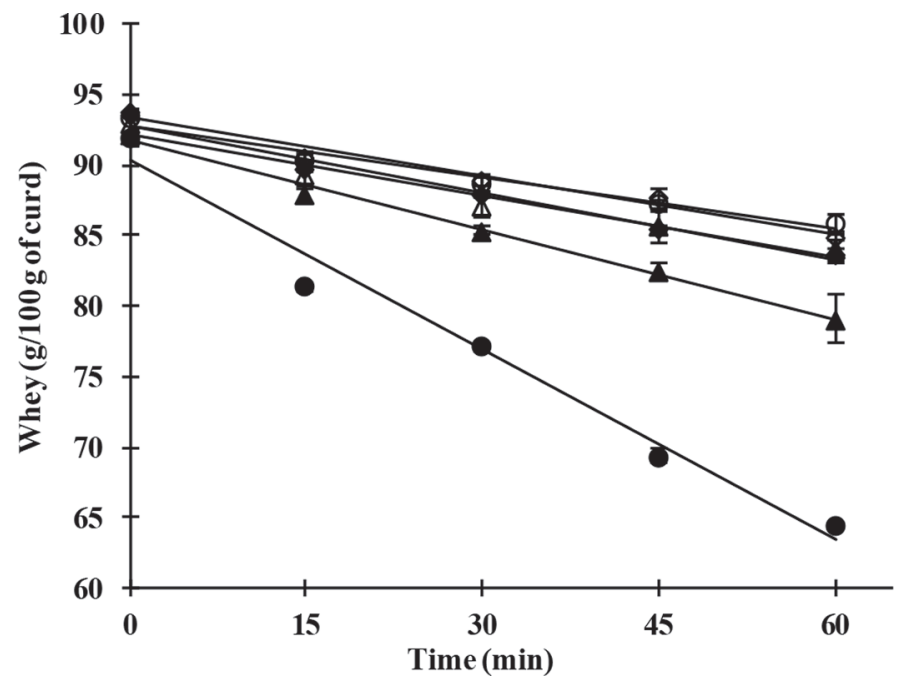

Figure 2. Whey loss in inoculated and noninoculated curds incubated at 3 temperatures. Noninoculated samples are represented by empty symbols: $30^{\circ} \mathrm{C}(\diamond), 35^{\circ} \mathrm{C}(\Delta)$, and $40^{\circ} \mathrm{C}(\bigcirc)$. Inoculated samples are represented by filled symbols: $30^{\circ} \mathrm{C}(\bullet), 35^{\circ} \mathrm{C}(\boldsymbol{\Delta})$, and $40^{\circ} \mathrm{C}(\bullet)$. Error bars indicate SD. contraction of the structure and the expulsion of whey (Renault et al., 1997; Walstra et al., 2005).

\section{Density}

Curd Density. Figure 3 shows changes in curd density observed during the 60 min of the study. Curd density increased in a linear trend with respect to time at a rate of $0.0003,0.0002$, and $0.0003 \mathrm{~g} / \mathrm{cm}^{3}$ per minute at 30,35 , and $40^{\circ} \mathrm{C}$, respectively, showing coefficients of determination higher than 0.9875 . Surprisingly, only the factors temperature and time were statistically significant $(P \leq 0.01)$. Lactic acid bacteria inoculation was not a statistically significant factor, indicating that $\mathrm{pH}$ does not play a relevant role in defining curd density during the studied period, as temperature and time do. These findings are intriguing because whey content of inoculated and noninoculated samples is very different, especially at longer curing times (Figure 2), and such marked composition difference was expected to cause a significant effect on curd density. It is also worth noting that although the factor temperature was statistically significant, the maximum observed density difference among treatments was less than $0.01 \mathrm{~g} / \mathrm{cm}^{3}$, which for practical purposes is a very small difference. Curd density was lower than whey density $(1.0221 \mathrm{~g} /$ $\mathrm{cm}^{3}$ ) during the first $30 \mathrm{~min}$ at all temperatures, implying that curds float on whey during the early phases of curd curing and cooking, as previously reported by Munro and Tan (1984), Van den Bijgaart (1988), and Walstra (1993).

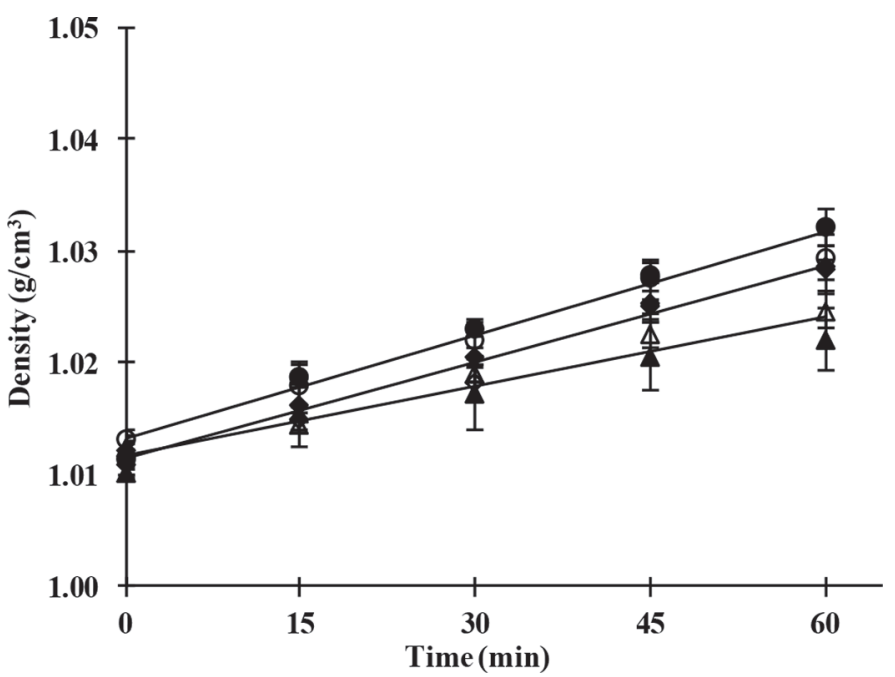

Figure 3. Density of inoculated and noninoculated curds incubated at 3 temperatures. Noninoculated samples are represented by empty symbols: $30^{\circ} \mathrm{C}(\diamond), 35^{\circ} \mathrm{C}(\Delta)$, and $40^{\circ} \mathrm{C}(\bigcirc)$. Inoculated samples are represented by filled symbols: $30^{\circ} \mathrm{C}(\diamond), 35^{\circ} \mathrm{C}(\boldsymbol{\Delta})$, and $40^{\circ} \mathrm{C}(\bullet)$. Error bars indicate SD. 
Table 1. Reported values of casein density in different forms in milk and curds

\begin{tabular}{lcll}
\hline Component & Density $\left(\mathrm{g} / \mathrm{cm}^{3}\right)$ & Method & Reference \\
\hline Rennet casein hydrated & $1.030-1.180$ & WD & Munro (1980) \\
Rennet casein dry & 1.453 & WD, MM & Munro (1980) \\
Lactic casein dry & 1.362 & WD, MM & Munro (1980) \\
Sulfuric acid casein dry & 1.385 & WD, MM & Munro (1980) \\
Calcium caseinate & 1.430 & WD, MM & Munro (1980) \\
Curd particle & 1.035 & NSp & Van den Bijgaart (1988) \\
Calcium paracaseinate & 1.390 & NSp & Van den Bijgaart (1988) \\
Curd particle & $1.028-1.057$ & WD & Akkerman (1992) \\
Paracaseinate & 1.438 & NSp & Walstra et al. (2005) \\
Casein micelle & 1.100 & NSp & de Kruif and Huppertz (2012) \\
Casein micelle & 1.078 & MM & de Kruif and Huppertz (2012) \\
Micellar solids (casein micelle plus micellar calcium phosphate) & 1.420 & NSp & Broyard and Gaucheron (2015) \\
Casein micelle & 1.063 & NSp & Fox et al. (2015) \\
Casein micelle & 1.036 & &
\end{tabular}

${ }^{1} \mathrm{WD}=$ water displacement $\mathrm{MM}=$ mathematical model; $\mathrm{NSp}=$ none specified.

Previous attempts to measure curd density have yielded results similar to the ones obtained in the present study (Table 1). Munro (1980) calculated the density of milk casein obtained by different means (lactic acid, sulfuric, and rennet), reporting that the density of rennet casein with high moisture content has a value of approximately $1.030 \mathrm{~g} / \mathrm{cm}^{3}$. Van den Bijgaart (1988) evaluated the effect of gravity-induced pressure on a recently formed gel, reporting a density of curd particles of $1.035 \mathrm{~g} / \mathrm{cm}^{3}$. Akkerman (1992) measured Gouda cheese curd density through flotation on sodium chloride solutions at different concentrations (5-9\%), obtaining values of density of the curds between 1.028 and $1.057 \mathrm{~g} / \mathrm{cm}^{3}$.

Protein Phase Density. Development of the calculated protein phase density of curds through time is shown in Figure 4. To avoid overlapping of the data, curves corresponding to noninoculated samples are plotted on the left side (panel a) and inoculated

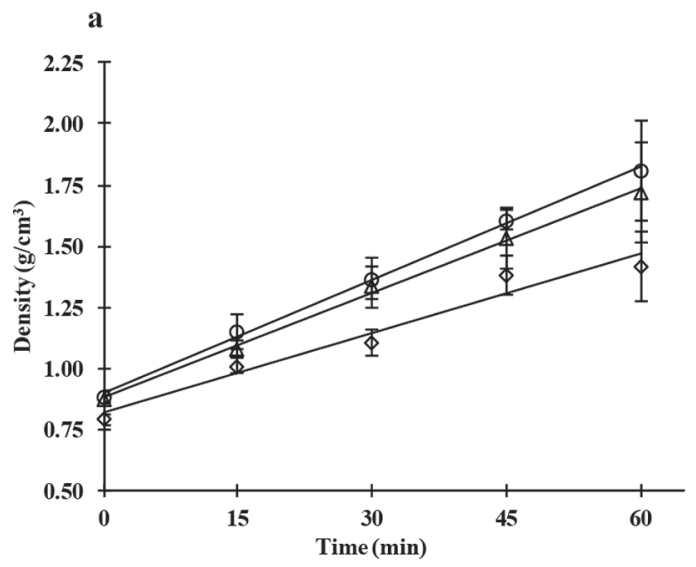

samples are presented on the right side (panel b). All studied samples showed an initial protein phase density of around $0.83 \mathrm{~g} / \mathrm{cm}^{3}$. However, noninoculated samples showed a temperature-dependent linear increase in their protein phase density up to $1.80 \mathrm{~g} / \mathrm{cm}^{3}\left(\mathrm{R}^{2}=\right.$ $0.960,0.997$, and 0.997 at 30,35 , and $40^{\circ} \mathrm{C}$, respectively), whereas inoculated samples showed a nonlinear increase in their protein phase density, changing slope at around 15 to $30 \mathrm{~min}$ and reaching a density of about $1.43 \mathrm{~g} / \mathrm{cm}^{3}$ after $60 \mathrm{~min}$ regardless of treatment temperature, showing asymptotic behavior. This value $\left(1.43 \mathrm{~g} / \mathrm{cm}^{3}\right)$ is similar to the one used by Van den Bijgaart (1988) when calculating the gravitational pressure exerted on curds; this study used a value of $1.39 \mathrm{~g} /$ $\mathrm{cm}^{3}$ for calcium paracaseinate. Similarly, Munro (1980) reported a value of $1.43 \mathrm{~g} / \mathrm{cm}^{3}$ for casein and caseinate in water suspension.

As described before, protein phase density was calculated based on the density and relative abundance of the

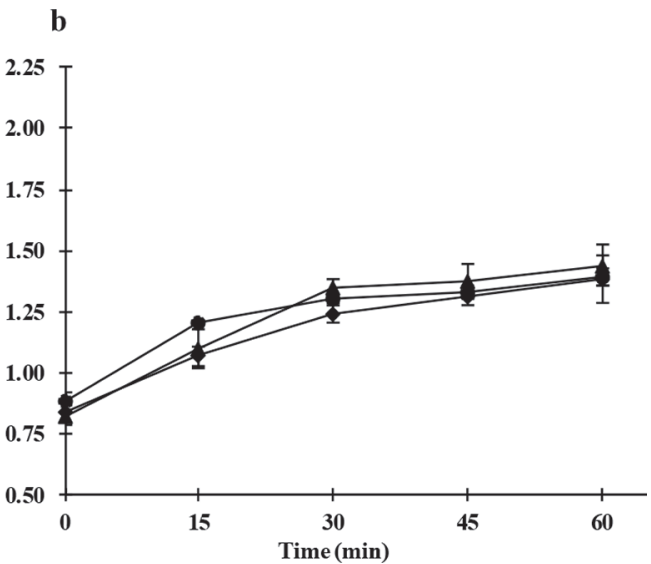

Figure 4. Protein phase density of inoculated and noninoculated curds incubated at 3 temperatures. Noninoculated samples are represented by empty symbols: $30^{\circ} \mathrm{C}(\diamond), 35^{\circ} \mathrm{C}(\Delta)$, and $40^{\circ} \mathrm{C}(\bigcirc)$. Inoculated samples are represented by filled symbols: $30^{\circ} \mathrm{C}(\bullet), 35^{\circ} \mathrm{C}(\boldsymbol{\Delta})$, and $40^{\circ} \mathrm{C}(\bullet)$. Error bars indicate SD. 
rest of the curd components using Equation 2. Whey mass fraction was estimated by considering moisture content and a TS content in whey of $6.61 \%$ (wt/wt), which is similar to the value of $6.8 \%$ (wt/wt) reported by Walstra et al. (2005). Dry-basis fat content of curds remained constant at approximately $3.21 \%$ (wt/wt) during the $60 \mathrm{~min}$ of the study, although its wet-basis value increased due to whey loss. On the other hand, the experimental values obtained in the present study for whey and fat density remained constant throughout the study, showing values of 1,022 and $0.914 \mathrm{~g} / \mathrm{cm}^{3}$, respectively. These values have great similarity to those reported in the literature for whey $\left(1.020-1.023 \mathrm{~g} / \mathrm{cm}^{3}\right.$; Akkerman, 1992; de Kruif and Huppertz, 2012) and fat (0.90-0.92 g/ $\mathrm{cm}^{3}$; Walstra et al., 2005; Fox et al., 2015).

The nonlinear behavior of inoculated samples shown in Figure $4 \mathrm{~b}$ resembles the result of the addition of 2 linear trends of different slope, suggesting 2 different phenomena with an effect on protein phase density happening at the same time. The first one, starting at time 0 , is a trend shared by inoculated and noninoculated samples, where temperature plays a relevant role. At this time, $\mathrm{pH}$ plays no role in protein phase density (the same trends are observed on inoculated and noninoculated samples). The second one, which becomes evident around 15 to $30 \mathrm{~min}$, is a different phenomenon that interferes with the first one, restraining inoculated samples from increasing their protein phase density in a temperature-dependent linear fashion as noninoculated samples do (although a new temperature-independent linear trend of different slope is set). This second phenomenon seems to be related to $\mathrm{pH}$ development, as the protein phase density of inoculated samples incubated at $30^{\circ} \mathrm{C}$ (slowest $\mathrm{pH}$ development) is very similar to that of noninoculated samples incubated at the same temperature. From these observations, we may conclude that what is witnessed in Figure 4a is the result of the unhindered aggregation of paracasein micelles through ionic (calcium mediated) and hydrophobic interactions, the later ones being strongly dependent on temperature (Carlson et al., 1986; Bansal et al., 2007; Kumar et al., 2010). On the other hand, the $\mathrm{pH}$ decrease observed in inoculated samples promotes the reduction in the net electrostatic charge of micelles, causing the solubilization of ionic calcium (Choi et al., 2015). This in turn causes the weakening of the protein structure and the reduction of the density of the protein phase (or rather prevents it from reaching the density values observed in noninoculated samples). Modification of the protein phase density by the presence of bacterial cells in inoculated samples (density $=1.035-1.093 \mathrm{~g} / \mathrm{cm}^{3}$; Bakken and Olsen, 1983) is another possible explanation for the differences observed in Figure $4 \mathrm{a}$ and $\mathrm{b}$. However, this seems unlikely because bacteria grow in an exponential fashion, whereas the observed effect seems to be linear.

\section{CONCLUSIONS}

Development of curd density under various temperature and $\mathrm{pH}$ conditions throughout a 60-min curing period is reported here for the first time. The protein phase density of inoculated and noninoculated curds was successfully calculated using the proposed methodology. Inoculated curd samples developed lower $\mathrm{pH}$ levels than noninoculated samples, concurrently showing higher whey loss during the curing process. Whey loss and $\mathrm{pH}$ showed a linear dependence with time and temperature. Higher incubation temperatures and longer incubation times induced larger $\mathrm{pH}$ decreases and higher whey loss. Density of all studied samples showed a small linear increase during the curing period. No difference in curd density was observed between inoculated and noninoculated samples. Although a slight effect of temperature was observed (higher incubation temperatures produced denser curds), the density of all studied curds behaved in a very similar way throughout curing time. This behavior was surprising because the whey content of inoculated and noninoculated samples differed greatly, and such composition differences were expected to have an influence on curd density. The radically different evolution of the protein phase density of inoculated and noninoculated curd samples suggested the existence of 2 independent mechanisms involved in the development of the protein-based structure of curds. Noninoculated curds displayed a larger increase in protein phase density, probably due to the concurrent action of calcium-mediated electrostatic bonds and temperature-dependent hydrophobic bonds. Inoculated curds, on the other hand, showed signs of weakening of the protein structure (compared with noninoculated samples), probably caused by calcium solubilization and the reduction in the net charge of paracasein micelles induced by the reduction in $\mathrm{pH}$. Further studies are necessary to corroborate these hypotheses.

\section{ACKNOWLEDGMENTS}

The authors thank Veronica Gonzalez and Angel Esparza (Centro de Investigacion en Alimentacion y Desarrollo A.C., Unidad Cuauhtemoc, Ciudad Cuauhtemoc, Chihuahua, Mexico) for their technical assistance. Author Amaro-Hernandez thanks the Mexican National Council of Science and Technology (CONACYT, Mexico City) for providing the financial support for his graduate studies. The authors have not stated any conflicts of interest. 


\section{REFERENCES}

Akkerman, J. C. 1992. Drainage of curd. PhD Diss. Wageningen University, Wageningen, the Netherlands.

AOAC International. 2002. Official Methods of Analysis. 17th ed. AOAC International, Gaithersburg, MD.

AOAC International. 2006. Official Methods of Analysis. 18th ed. AOAC International, Gaithersburg, MD.

Bakken, L. R., and R. A. Olsen. 1983. Buoyant densities and drymatter contents of microorganisms: Conversion of a measured biovolume into biomass. Appl. Environ. Microbiol. 45:1188-1195.

Bansal, N., P. F. Fox, and P. L. McSweeney. 2007. Aggregation of rennet-altered casein micelles at low temperatures. J. Agric. Food Chem. 55:3120-3126. https://doi.org/10.1021/jf0631427.

Brovard, C., and F. Gaucheron. 2015. Modifications of structures and functions of caseins: A scientific and technological challenge. Dairy Sci. Technol. 95:831-862. https://doi.org/10.1007/s13594-015 $-0220-y$.

Carlson, A., G. C. Hill, and N. F. Olson. 1986. The coagulation of milk with immobilized enzymes: A critical review. Enzyme Microb. Technol. 8:642-650. https://doi.org/10.1016/0141-0229(86)90059 -1 .

Choi, J., D. Horne, and J. Lucey. 2015. Effect of insoluble calcium concentration on endogenous syneresis rate in rennet-coagulated bovine milk. J. Dairy Sci. 98:5955-5966. https://doi.org/10.3168/ jds.2015-9527.

Dalgleish, D. G., and A. J. R. Law. 1988. pH-induced dissociation of bovine casein micelles. I. Analysis of liberated caseins. J. Dairy Res. 55:529-538. https://doi.org/10.1017/S0022029900033306.

de Kruif, C. G., and T. Huppertz. 2012. Casein micelles: Size distribution in milks from individual cows. J. Agric. Food Chem. 60:4649-4655. https://doi.org/10.1021/jf301397w.

Fox, P. F., and T. P. Guinee. 2013. Cheese science and technology. Pages 357-389 in Milk and Dairy Products in Human Nutrition: Production, Composition and Health. 1st ed. P. A. Haenlein, ed. Wiley, Hoboken, NJ.

Fox, P. F., T. P. Guinee, T. M. Cogan, and P. L. McSweeney. 2017. Fundamentals of Cheese Science. Springer, New York, NY.

Fox, P. F., T. Uniacke-Lowe, P. L. H. McSweeney, and J. A. O'Mahony. 2015. Dairy Chemistry and Biochemistry. Springer International Publishing, Cham, Switzerland.

Gonçalves, M. C., and H. R. Cardarelli. 2019. Composition, microstructure and chemical interactions during the production stages of Mozzarella cheese. Int. Dairy J. 88:34-41. https://doi.org/10 .1016/j.idairyj.2018.07.005.

Hickey, C., M. Auty, M. Wilkinson, and J. Sheehan. 2015. The influence of cheese manufacture parameters on cheese microstructure, microbial localisation and their interactions during ripening: A review. Trends Food Sci. Technol. 41:135-148. https://doi.org/10 .1016/j.tifs.2014.10.006.

Horne, D. S., and J. M. Banks. 2004. Rennet-induced coagulation of milk. Pages 47-70 in Cheese: Chemistry, Physics and Microbiology. Vol. 1: General Aspects. P. F. Fox, P. L. H. McSweeney, T. M. Cogan, and T. P. Guinee, ed. Elsevier, Amsterdam, the Netherlands.

Janhøj, T., and K. Qvist. 2010. The formation of cheese curd. Pages 130-165 in Technology of Cheesemaking. 2nd ed. B. A. Law and A. Y. Tamime, ed. Wiley-Blackwell, Ames, IA.

Kumar, A., S. Grover, J. Sharma, and V. Batish. 2010. Chymosin and other milk coagulants: Sources and biotechnological interventions. Crit. Rev. Biotechnol. 30:243-258. https://doi.org/10.3109/ 07388551.2010 .483459

Lodaite, K., K. Östergren, M. Paulsson, and P. Dejmek. 2000. Onedimensional syneresis of rennet-induced gels. Int. Dairy J. 10:829 834. https://doi.org/10.1016/S0958-6946(01)00027-9.

Lucey, J. 2011. Curd syneresis. Pages 591-594 in Encyclopedia of Dairy Sciences. 2nd ed. J. W. Fuquay, ed. Academic Press, Cambridge, MA.
Lucey, J. A. 2014. Milk protein gels. Pages 493-523 in Milk Proteins: From Expression to Food. 2nd ed. M. Boland, H. Singh, and A. Thompson, ed. Academic Press, Cambridge, MA.

Marshall, R. J. 1982. An improved method for measurement of the syneresis of curd formed by rennet action on milk. J. Dairy Res. 49:329-336. https://doi.org/10.1017/S0022029900022433.

Meakin, P. 1987. Fractal aggregates. Adv. Colloid Interface Sci. 28:249-331. https://doi.org/10.1016/0001-8686(87)80016-7.

Mellema, M., J. Heesakkers, J. Van Opheusden, and T. van Vliet. 2000. Structure and scaling behavior of aging rennet-induced casein gels examined by confocal microscopy and permeametry. Langmuir 16:6847-6854. https://doi.org/10.1021/la000135i.

Mellema, M., P. Walstra, J. Van Opheusden, and T. van Vliet. 2002. Effects of structural rearrangements on the rheology of rennetinduced casein particle gels. Adv. Colloid Interface Sci. 98:25-50. https://doi.org/10.1016/S0001-8686(01)00089-6.

Munro, P. 1980. The densities of casein curd particles and caseinate solutions. N. Z. J. Dairy Sci. 15:225-238.

Munro, P. A., and B. K. Tan. 1984. Inclusion of gas in casein and leaf protein precipitate particles and its effect on particle density. J. Chem. Technol. Biotechnol. 34:279-290. https://doi.org/10.1002/ jetb. 280340408 .

O'Callaghan, D. 2011. Gel firmness and its measurement. Pages 585590 in Encyclopedia of Dairy Sciences. 2nd ed. J. W. Fuquay, ed. Academic Press, Cambridge, MA.

Ong, L., R. R. Dagastine, S. E. Kentish, and S. L. Gras. 2011. Microstructure of milk gel and cheese curd observed using cryo scanning electron microscopy and confocal microscopy. Lebensm. Wiss. Technol. 44:1291-1302. https://doi.org/10.1016/j.lwt.2010.12.026.

Özilgen, M., and R. J. Kauten. 1994. NMR analysis and modelling of shrinkage and whey expulsion in rennet curd. Process Biochem. 29:373-379. https://doi.org/10.1016/0032-9592(94)87007-1.

Renault, C., E. Gastaldi, A. Lagaude, J. Cuq, and B. T. Fuente. 1997. Mechanisms of syneresis in rennet curd without mechanical treatment. J. Food Sci. 62:907-910. https://doi.org/10.1111/j.1365 -2621.1997.tb15004.x.

Sørensen, J., D. S. Palmer, K. B. Qvist, and B. Schiøtt. 2011. Initial stage of cheese production: A molecular modeling study of bovine and camel chymosin complexed with peptides from the chymosinsensitive region of $\kappa$-casein. J. Agric. Food Chem. 59:5636-5647. https://doi.org/10.1021/jf104898w.

Van den Bijgaart, H. J. C. M. 1988. Syneresis of rennet-induced milk gels as influenced by cheesemaking parameters. PhD Diss. Department of Food Science, Wageningen Agricultural University, Wageningen, the Netherlands.

van Vliet, T., C. M. Lakemond, and R. W. Visschers. 2004. Rheology and structure of milk protein gels. Curr. Opin. Colloid In. 9:298-304

van Vliet, T., and P. Walstra. 1994. Water in casein gels; How to get it out or keep it in. J. Food Eng. 22:75-88. https://doi.org/10.1016/ 0260-8774(94)90026-4.

Walstra, P. 1993. The syneresis of curd. Pages 141-191 in Cheese: Chemistry, Physics and Microbiology. P. F. Fox, ed. Springer, New York, NY.

Walstra, P., P. Walstra, J. T. Wouters, and T. J. Geurts. 2005. Dairy Science and Technology. CRC Press, Boca Raton, FL.

Yadav, J. S. S., S. Yan, S. Pilli, L. Kumar, R. Tyagi, and R. Surampalli. 2015. Cheese whey: A potential resource to transform into bioprotein, functional/nutritional proteins and bioactive peptides. Biotechnol. Adv. 33:756-774. https://doi.org/10.1016/j.biotechadv 2015.07.002.

\section{ORCIDS}

N. Gutiérrez-Méndez @ https://orcid.org/0000-0002-0791-3211

D. R. Sepulveda (ํ) https://orcid.org/0000-0002-0400-8873 